\title{
Evaluating policy responses to noncommunicable diseases in seven Caribbean countries: challenges to addressing unhealthy diets and physical inactivity
}

\author{
Madhuvanti M. Murphy, ${ }^{1}$ Nigel Unwin, ${ }^{2}$ T. Alafia Samuels, ${ }^{3}$ Trevor A. Hassell, ${ }^{4}$ Lisa Bishop, ${ }^{1}$ \\ and Cornelia Gue//5
}

Suggested citation Murphy MM, Unwin N, Samuels TA, Hassell TA, Bishop L, Guell C. Evaluating policy responses to noncommunicable diseases in seven Caribbean countries: challenges to addressing unhealthy diets and physical inactivity. Rev Panam Salud Publica. 2018;42:e174. https://doi.org/10.26633/ RPSP.2018.174

\begin{abstract}
Objective. To identify, assess, and compare existing policies on noncommunicable diseases (NCDs) in the Caribbean, gaps in policy responses, and the factors influencing successful policy development and implementation following the Port of Spain Declaration of 2007. Specifically, to examine policies that target the upstream determinants of two NCD risk factors - unhealthy diets and physical inactivity.

Methods. A total of 76 semi-structured interviews with 80 relevant stakeholders in government, the private sector, and civil society were complemented by policy document analysis. Interviews were analyzed pragmatically, framed by the CARICOM government commitments, the WHO NCD Action Plan, a Multiple Streams framework approach, and realist evaluation ideas.

Results. The most widely-reported policy successes involved health promotion activities (e.g., school meal programs) that leveraged multisectoral collaboration among government ministries, such as Health, Education, and Agriculture. Large policy gaps still exist around creating legislative, physical, and social environments to support healthy eating and physical activity at the population level. Multisectoral NCD commissions successfully reached across sectors, but had limited influence on policy development. Different policy levels emerged with national-level policies considered a lengthy process, while "On-the-ground" programming was considered faster to implement than national policies. External barriers included a reliance on food imports enabled by international trade agreements limited availability, quality, and affordability of healthy foods. International pushback limited legislation to reduce food imports and the absence of an international/regional framework, similar to the Framework Convention on Tobacco Control, further impedes efforts.

Conclusions. Regional collaboration and political support across sectors are essential to accelerating the pace of action to support healthy eating and active living environments. Policy "blueprints" could accelerate the process of development. Regional "NCD champions" could spearhead such responses and approaches.
\end{abstract}

Keywords Noncommunicable diseases; policy making; health policy; exercise; nutrition, public health; Caribbean region.

\footnotetext{
Faculty of Medical Sciences, University of the West Indies, Cave Hill Campus, Barbados. Send correspondence to Madhuvanti M. Murphy, madhuvanti.murphy@cavehill.uwi.edu
}

\footnotetext{
Medical Research Council Epidemiology Unit and Centre for Diet and Activity Research, University of Cambridge, Cambridge, United Kingdom.

3 George Alleyne Chronic Disease Research Centre, University of the West Indies, Bridgetown, Barbados.
}
Healthy Caribbean Coalition, Bridgetown, Barbados.
European Centre for Environment \& Human Health, University of Exeter Medical School, Truro, United Kingdom.


The World Health Organization (WHO) Global Action Plan for the Prevention and Control of Noncommunicable Diseases (NCD), 2013 - 2020, highlights the important role of governments in responding to the NCD challenge and the need for action through multisectoral collaboration (1). Similarly, the WHO World Conference on Social Determinants of Health underscores the need to understand political agendas, as well as to evaluate the policy process, multisectorality within governments, and all-of-society approaches to health (2). In 2014, the Caribbean Community (CARICOM) and the Pan American Health Organization (PAHO), Regional Office of $\mathrm{WHO}$ for the Americas, commissioned the evaluation of the Port of Spain Summit Declaration, "Uniting to Stop the Epidemic of Chronic NonCommunicable Diseases" (the POS Declaration). Originally issued by the CARICOM Heads of Government in 2007, the POS Declaration has 15 mandates with 27 commitments that include improving diet and increasing physical activity (3).

Seven years after it was issued, implementation of the POS Declaration was evaluated, aiming to leverage lessons learned, accelerate further implementation, and inform the WHO Global Monitoring Framework for NCDs (4). One aspect of the "Evaluation of CARICOM's Political Commitments for NonCommunicable Disease Prevention and Control," (otherwise called the POS Evaluation or POSDEVAL) examined indicators that monitor annual compliance with the mandates of the POS Declaration (5). Six of the seven indicators related to policy responses designed to address the macro-determinants "diet" and "physical activity" were ranked as having poor compliance (i.e., the lowest level of implementation). Sufficient action had not been taken in areas such as food labeling, banning trans-fats, trade agreements on food, physical activity programs, and healthy eating campaigns. In fact, fewer than $50 \%$ of CARICOM Member States reported being "in compliance" or "being in the process" of complying with the diet and physical activity mandates.

This article reports findings from the qualitative research component of the POS Evaluation, which identified existing policies for NCD prevention and control, gaps in policy responses, and factors that have promoted or hindered successful policy development and implementation in seven countries in the
Caribbean. The study objective was to examine policy measures intended to address the upstream determinants of two NCD risk factors with the lowest policy implementation-unhealthy diets and physical inactivity-in order to better understand the successes and challenges.

\section{MATERIALS AND METHODS}

\section{Study design and settings}

Detailed case studies were conducted in April 2015 - July 2015 in seven countries/territories of the English-speaking Caribbean: Antigua and Barbuda, Belize, British Virgin Islands, Grenada, Jamaica, St. Kitts and Nevis, and Trinidad and Tobago. These countries were selected to represent diversity of size, compliance with policy implementation, and to include full and associate members of CARICOM.

In all, 76 semi-structured interviews with 80 stakeholders were conducted, building on a previous pilot study in Barbados (6). The seven case studies explored policy responses to NCDs among diverse key stakeholders, including the government, private sector, and civil society organizations. The interviews aimed to understand the degree and nature of policy responses to NCDs and the factors that have promoted or hindered their effectiveness (Supplementary Materials, including an interview guide, are available upon request from the corresponding author). Data was collected by two teams of interviewers from the University of the West Indies at Cave Hill, Barbados (lead site), and at Mona, Jamaica (two teams of three interviewers each). Interviewers used the standard operating procedures created for the study. Stakeholders were identified through stakeholder analysis (i.e., identified by those working within the topic area in each country) and by "cascading" (asking for suggestions from stakeholders already interviewed). All potential stakeholders were invited to be interviewed; those who agreed, participated. Interviews were conducted until saturation was achieved: $7-25$ interviews, $30-60$ minutes in length, per country.

\section{Data analysis}

All interviews were recorded and transcribed verbatim. The analysis of the relatively large qualitative dataset required a pragmatic, partly deductive approach, although emerging inductive insights were also included in the analysis. In a series of workshops, the entire research team guided the processes and ensured the rigor of the analysis. This included the development of a coding scheme, which was applied to the data by a team of 10 coders using the qualitative analysis software, Dedoose Version 8.0.35 (SocioCultural Research Consultants, Los Angeles, California, United States). Deductive codes captured key concepts of the WHO Global Action Plan on NCDs with terms such as "governance," "risk factors," and "multisectorality," (1); and of the theoretical Multiple Streams Framework (7), with terms such as "policy entrepreneurs" and "problem definition." After initial coding, two lead researchers synthesized the analyses; this was further informed by the question at the heart of Realist evaluation (8): "What works for whom under what circumstances?" This included comparing and contrasting among the seven case-study settings and exploring how differences in policymaking might be attributable to differences in context.

\section{Ethics}

The study received ethical approval from the Institutional Review Board of the University of the West Indies (Cave Hill, Barbados) and from the Ministry of Health (or most relevant body) of each of the seven countries/territories. Stakeholders were interviewed in their professional or public capacity; no personal information was requested.

\section{RESULTS}

\section{Multisectoral collaboration required}

Across all countries, stakeholders reported a commonly shared recognition of the need for multisectoral partnerships to guide regional policy development, adaptation, and implementation in their local settings. Policies and guidelines that were considered successful were those created through a collaborative effort. Many countries created NCD commissions as a commitment to the POS Declaration. These quasigovernmental advisory boards represented relevant sectors and stakeholders. They expressed both the positives of 
achieving collaboration and the difficulties of obtaining equitable representation, sustaining functionality through political transitions, and translating recommendations into government action.

NCD commissions allowed for a "whole of society," collaborative approach by including the perspectives of civil society, industry/private sector, and non-health public sectors (e.g., agriculture and education). Their power to enact change was often limited, however, by their role as mere advisors to the government despite some possessing the expertise required to develop much-needed policies.

While the NCD commission provided a framework for multisectoral work, indicating who should sit at the table, formal supportive structures or processes of influence were not defined. Recommendations given by the commissions were often not considered or translated into policy. Also, commission members in smaller settings often represented several sectors. This expertise on a broad range of sectors could be beneficial, but also problematic, as personal agendas might shape perspectives. In particular, no formal process existed by which the individual commission members could be consulted or held accountable by the sectors they represented.

Multisectoral action within government seemed more successful in a few cases, perhaps enabled through the POS Declaration and in contexts with a history of collaboration. When developing policies related to physical activityincreasing physical activity in schools, for example-collaboration within and among ministries (e.g., the Ministry of Education and the Ministry of Health) enabled a successful policy process:

$$
\begin{aligned}
& \text { "... for a long time, we have worked } \\
& \text { in silos. Each ministry is doing its } \\
& \text { own thing, but we have recognized } \\
& \text { the importance of collaborating with } \\
& \text { each other. I am happy to say that } \\
& \text { we have come a long way in having } \\
& \text { collaboration with the Ministry of } \\
& \text { Health ... to work with them in } \\
& \text { helping the young people in our } \\
& \text { schools." (Government stakeholder) }
\end{aligned}
$$

Other initiatives, such as those that go beyond sports and structured exercise to promote "active living" within supportive physical environments, were relatively limited. This may have been partially due to stakeholder concern that an agenda of "health in all remits," (health in all sectors) lacked capacity to reach out to other ministries.

Similar challenges of multisectoral partnering were experienced when creating food guidelines, which for some countries had input from the Ministries of Agriculture, Education, and/or Health. Yet such input was often limited, and sectors with weaker ties to the Ministry of Health, such as the business, trade, and finance sector, were less engaged. It was notable that most policies around diet and physical activity were either still in development or had just recently been developed; few to none were in the implementation stage; and clear leadership was often missing.

Individuals who held significant roles and traction across sectors-policy entrepreneurs (7)-were identified as the most effective representatives for multisectoral collaboration and could act as lobbyists for the NCD cause. Particularly effective were those policy entrepreneurs who also led NCD commissions. Stakeholders raised concerns, however, that such champions had little lasting impact because there was no succession planning, and therefore, multisectorality was not formally institutionalized.

"My concern is that if [current policy entrepreneur] isn't around for whatever reason...I think everything would cease and I think that is poor succession planning." (Civil society stakeholder)

\section{“Policy levels" matter}

This evaluation followed the widely accepted definition of NCD public policies as, "broad statements made by government of goals, objectives, and means in order to create a framework for activity directed at the prevention and control of NCDs. Such statements may be written or unwritten, explicit or implicit" (9). Across the countries, however, a different definition of "NCD policies" emerged from stakeholders. "Policies" were discussed as population-level regulations that needed ratification at the national level prior to implementation; "guidelines" were used to describe smaller-scale policies developed within ministries; and "programs" were typically carried out by civil society organizations, corporate industry, and/or private citizens. In other words, stakeholders distinguished between ratified government legislation versus broad intentions or concrete action by government or other sectors. A general finding was that population-level policies were slow to be ratified and implemented, making little difference "on the ground." Stakeholders suggested that most progress had been the result of personal commitment by a few individuals in creating programs through government and private businesses. This applied to both larger, wealthier countries with more resources and capacity, and to smaller countries that commonly receive international aid.

Also, while stakeholders considered the mandates around diet and physical activity to be focused on population-level policy development and implementation logistically and practically, both were difficult due to limited resources. For instance, the lack of personnel trained in policy development increased reliance on foreign consultants. This shortage also meant that developing solid policies could take years, explaining why many diet- and physical activity-related policies had only reached the government approval phase at the 7-year mark:

“...we established an ad hoc committee within the Ministry, but we found it extremely challenging with our regular work to actually work on the document. So, it took a very, very long time. And we would have preferred if we could have had a consultant from [home country] who was aware of our situation, who could dedicate a month to the policy rather than stretching it out over a year." (Government stakeholder)

While there were existing policy actions related to diet and nutrition (all but one country had food and nutrition guidelines), most discussions focused on challenges in developing and implementing policies addressing physical activity. No country explicitly had physical activity guidelines at a population level. Stakeholders within ministries agreed that it was easier and quicker to implement guidelines (which carried a less extensive and/or formalized policy process depending on the country) within individual schools and 
programs within communities than at the national level.

Physical activity was, therefore, mainly addressed through school programs (for children) or small community programs (for adults). On a national level, 5-K runs, which usually occur sporadically throughout the year to raise health awareness, were very popular in most countries. Several corporate agencies sponsored such races, and while these actions may be within their corporate responsibility policies, they were not a response to the POS Declaration. Physical activity promotion through private businesses also experienced high levels of community involvement. Unfortunately, these types of programs lacked monitoring and evaluation to determine their true impact on NCDs, and sustainability of programs was often hampered by short-term and/or external funding.

Similarly, for nutrition, privatelyled actions were considered effective, though rare; a notable example in one island was recounted by a stakeholder of another country as a commendable example:

"...one of the big bakeries ... which used to use a lot of salt in their bread, they asked them to lower the amount of salt, so they started very gradually lowering the amount of salt ... and nobody has noticed...the public hasn't noticed." (Civil society stakeholder)

It was clear that the bureaucratic processes and "red tape," created challenges to addressing population-level policies highlighted in the POS Declaration, e.g., food labeling and banning trans-fats. Addressing these challenges was perceived as complicated by larger, international players in the food and trade industries creating pushback to policy implementation.

\section{Pushback limits legislation}

Stakeholders across the countries and sectors reported a host of external barriers to addressing NCD risk factors, particularly those related to nutrition. Awareness of healthy eating was generally regarded as low, and the proliferation of nutritionally-poor fast food is cause for concern. However, the most often highlighted and pressing issues for

policymakers was food insecurity-a significant proportion of the population financially unable to purchase healthy foods and a deepening reliance on food imports. This lack of food sovereignty limits the reach of legislative action on the quality and affordability of healthy foods and more:

\begin{abstract}
"Most of the food is imported... there are some farms in the United States and Canada that are bigger than [our country], so they have the volume, and so, by the time this stuff gets here it's cheaper. And, then you couple that with a cable television network that is ubiquitous, and there are no advertisements for healthy food on cable TV. What you see, as you know is, if you want to be cool, with it, and part of the crowd, then, you eat KFC, Dominos and stuff like that." (Government stakeholder)
\end{abstract}

Many CARICOM governments have considered taxing imported foods. However, concerns were raised that trade agreements could affect the economies of individual countries by taxing processed/ fast foods, and that developed nations could retaliate under the World Trade Organization rules.

“...we introduced VAT [Value Added Tax] 3 years ago and we thought it was the perfect opportunity to put higher taxes, the sin tax as you call it, on the imported, processed stuff and subsidize our farmers so that these things are healthier for them... [But] we can't do that. Why? World Trade Organization rules, no barriers...once you start to understand the system, and what a barrier stops prevents a politician from doing what's right." (Government stakeholder)

These macro-level barriers were experienced across all seven countries. However, smaller countries shared additional vulnerabilities, including less capability for food processing in their own country; export of fresh produce to bigger neighboring countries for larger profits and exposure to Caribbean-owned supermarkets; and natural barriers, such as geography and limited water for agriculture.

\section{DISCUSSION}

In summary, this analysis focused on policy implementation in seven casestudy settings to address the upstream risk factors of NCD: unhealthy diets and physical inactivity. Our findings for the Caribbean region echo challenges in NCD policymaking around the world in lower- and middle-income countries (10). They also resonate with several concepts within the larger policy-analysis literature; in particular, with more recent understandings of policymaking as a non-linear, complex, sometimes messy process that lacks formal structures and evidence base $(11,12)$. This understanding often played out in our study as individualized, informal policymaking across settings-policy actions that hinged on one individual pushing the agenda forward or connecting sectors (13).

This study confirms a previous analysis in a case-study setting in which the Multiple Streams Framework helped us to understand the POS Declaration as a policy window that opened when political will enabled "up-stream" NCD policy responses to transcend public health sector actions (7). Policy entrepreneurs also played a crucial role in this. The present analysis of seven case studies provided further in-depth data to understand why this policy window did not have more impact. Mandates such as multisectoral collaboration often lacked clear structures, capacity, and/or processes beyond articulating an ideal vision of working together. Power over decision-making laid elsewhere, leading to long, bureaucratic, unclear, and frustrating decision-making processes.

Framing policy-making as a messy process also helps to understand conflicting perceptions of what constitutes "policy." Our academic definition of policy, which incorporated unwritten commitments and actions, stood in contrast with our stakeholders' insistence of distinguishing between powerful, but lengthy legislative actions, and guidelines and programs on the ground. Their explicit labeling of different aspects of policy highlighted the value placed on a policy's degree of influence and reach. Perhaps a more useful term around the POS commitments would be "ideas," followed by an analysis of how these ideas were translated in national settings 
using the approach of "punctuated equilibrium" (14). This approach considers that all sectors, including the public, have limited resources and can pay limited attention to policy agendas; therefore, only the ideas that make the top of the agenda continue to have traction. For example, in our case settings, agendas shifted quickly from "whole of government" attention to NCDs, to the need for the public health sector to achieve buy-in from other sectors, and efforts by the NCD commission to make itself heard. Additionally, when met with challenging economic barriers, agendas shifted from complex structural and legislative NCD policies (outlined by the regional POS Declaration) to "easy wins" in health promotion.

\section{Recommendations}

To address the challenges identified in government actions, some stakeholders suggested that clearer blueprints (policy transfer) of existing diet and/or physical activity policies could help turn political commitments, "ideas," into concrete policies (14). Following the model of tobacco control policies (e.g., the Framework Convention on Tobacco Control), policies could be tailored to each country's context. The Framework's strengths lie in its legislative action over advice and advocacy as favored by other international examples, such as the Global Strategy for Diet and Physical Activity (15). Similarly, while the aspiration towards multisectorality is well established within public health and described in international policy documents (4), little detail is provided on how multisectoral partnerships can be achieved. Stakeholders suggested that blueprints need not come from sources outside of the Caribbean region, but that regional efforts could be more effectively shared. Successful NCD commissions in some settings, for example, that achieved more equitable representation or influence, could serve as good practice examples for others.

It was also suggested by stakeholders that a non-governmental, regional body take the form of "NCD Champion" to push for policy development, implementation, and enforcement. In addition, more research might be needed to identify successful "active ingredients" of multisectoral working. Other conceptual approaches within public health, such as knowledge exchange (16) and patientcenteredness, have developed their own research fields that inform policy and practice. By comparison, multisectoral collaboration still seems to be an underdeveloped research field $(17,18)$.

Finally, stakeholders in all the case studies noted the global challenge for Small Island Developing States and other low- and middle-income countries of macroeconomic forces negatively impacting their populations' access to affordable and nutritious food $(19,20)$. The challenges that stakeholders had found around macroeconomics also echoed, in part, ideas around commercial determinants of health (21). Stakeholders suggested that, at a minimum, addressing these issues requires regional cooperation on food labeling, transfat-free imports, and more.

Similarly, working to provide an international trade environment that enables countries to protect and promote local food production also requires regional cooperation, including the involvement of the CARICOM Council for Trade and Economic Development (Georgetown, Guyana) and the Caribbean Court of Justice (Port of Spain, Trinidad and Tobago). Other fora should also be leveraged, i.e., the United Nations Conference on Small Island Developing States and the G33 group of developing countries. Several stakeholders also believed that until international trade rules and regulations are modified or changed to enable the protection of local agriculture and food production for local consumption, the reliance on energy dense, nutritionally poor, imported foods will continue.

\section{Conclusions}

Although the political commitment of the POS Declaration created an opportunity to curve the rising NCD burden in the Caribbean, individual countries experienced a range of barriers to action. Addressing two important upstream determinants of NCD risk factors-unhealthy eating and physical inactivity-has been particularly challenging. Cooperation across sectors, within countries, and across countries might be the key to overcoming some of these challenges (22). We hope these recommendations can inform effective policy development and implementation across CARICOM, especially in Small Island Developing States.

Funding. This research was funded by the International Development Research Centre (Ottawa, Ontario, Canada; Grant \#107604-001). The funders had no role in the study design, data collection or analysis, decision to publish, or preparation of the manuscript.

\section{Conflict of interests. None declared.}

Disclaimer. Authors hold sole responsibility for the views expressed in the manuscript, which may not necessarily reflect the opinion or policy of the RPSP/ PAJPH and/or PAHO.

\section{REFERENCES}

1. World Health Organization. Global action plan for the prevention and control of noncommunicable diseases, 2013-2020. Geneva: WHO; 2013. Available from: www.who.int/nmh/events/ncd_action_ plan/en/ Accessed 13 July 2018.

2. World Health Organization. Closing the gap: policy into practice on social determinants of health: discussion paper. Geneva: WHO; 2011.
3. Caribbean Community and Common Market. Stemming the tide of noncommunicable diseases in the Caribbean. Trinidad and Tobago: CARICOM; 2007.

4. World Health Organization. NCD Global Monitoring Framework: ensuring progress on noncommunicable diseases in countries. Geneva: WHO; 2013. Available from: www. who.int/nmh/global_monitoring_framework/en/ Accessed 28 October 2016.
5. Samuels TA, Kirton J Guebert J. Monitoring compliance with high-level commitments in health: the case of the CARICOM Summit on Chronic Non-Communicable Diseases. Bull World Health Organ. 2014;92(4):270-6B.

6. Unwin N, Samuels TA, Hassell T, Brownson RC, Guell C. The development of public policies to address noncommunicable diseases in the Caribbean country of Barbados. Int J Health Policy Manag. 2017;6(2):71-82. 
7. Zahariadis N. The Multiple Streams Framework: structure, limitations, prospects. In: Sabatier P, ed. Theories of the Policy Process. 2nd ed. Cambridge (United States): Westview Press; 2007.

8. Pawson R, Tilley N. Realistic evaluation. London: Sage; 1997.

9. Buse K, Mays N, Walt G. Making Health Policy. 2nd ed. Maidenhead, Berkshire: Open University Press; 2012.

10. Juma PA, Mohamed SF, Wisdom J, Kyobutungi C, Oti S. Analysis of noncommunicable disease prevention policies in five Sub-Saharan African countries: study protocol. Arch Public Health. 2016; 74(1):25.

11. Biswas T, Pervin S, Tanim MIA, Niessen L, Islam A. Bangladesh policy on prevention and control of non-communicable diseases: a policy analysis. BMC Public Health. 2017;17(1):582.

12. Mukanu MM, Zulu JM, Mweemba C, Mutale W. Responding to non-communicable diseases in Zambia: a policy analysis. Health Res Policy Syst. 2017;15(1):34.
13. Brownson RC, Chriqui JF, Stamatakis KA. Understanding evidence-based public health policy. Am J Public Health. 2009; 99(9):1576-83.

14. Cairney P. The role of ideas in policy transfer: the case of UK smoking bans since devolution. J Eur Public Policy. 2009;16(3):471-88.

15. Magnusson RS. Non-communicable diseases and global health governance: enhancing global processes to improve health development. Global Health. 2007;3(1):2.

16. Contandriopoulos D, Lemire M, Denis J-L, Tremblay E. Knowledge exchange processes in organizations and policy arenas: a narrative systematic review of the literature. Milbank Q. 2010;88(4):444-83.

17. Armstrong R, Doyle J, Lamb C, Waters E. Multi-sectoral health promotion and public health: the role of evidence. J Public Health. 2006;28(2):168-72.

18. Guell C, Mackett R, Ogilvie D. Negotiating multisectoral evidence: a qualitative study of knowledge exchange at the intersection of transport and public health. BMC Public Health. 2017;17(1):17.
19. Chopra M, Darnton-Hill I. Tobacco and obesity epidemics: not so different after all? BMJ. 2004;328(7455):1558-60.

20. Hawkes C. Uneven dietary development: linking the policies and processes of globalization with the nutrition transition, obesity and diet-related chronic diseases. Global Health. 2006;2(1):4.

21. Kickbusch I, Allen L, Franz C. The commercial determinants of health. Lancet Global Health. 2016;4(12):e895-e6.

22. World Health Organization. Montevideo roadmap 2018-2030 on NCDs as a sustainable development priority. Proceedings of the WHO Global Conference on NCDs in Montevideo, Uruguay, 18-20 October 2017. Montevideo: WHO; 2017.

Manuscript received on 18 April 2018. Accepted for publication on 17 July 2018. 
RESUMEN Objetivo. Identificar, evaluar y comparar las políticas existentes sobre enfermedades no transmisibles (ENT) en el Caribe, las brechas en las respuestas políticas y los factores que influyeron en el desarrollo y la implementación de políticas exitosos

Evaluación de las respuestas políticas a las enfermedades no transmisibles en siete países del Caribe: desafíos para abordar las dietas no saludables y la inactividad física luego de la Declaración de Puerto de España en 2007. Específicamente, examinar las políticas que se enfocan en dos factores de riesgo de ENT: las dietas no saludables y la inactividad física.

Métodos. Se efectuaron 76 entrevistas semiestructuradas a 80 interesados relevantes pertenecientes al gobierno, el sector privado y la sociedad civil, y la información obtenida se complementó con un análisis de los documentos sobre las políticas. Las entrevistas se analizaron pragmáticamente en el marco de los compromisos de los gobiernos del CARICOM, el Plan de Acción sobre las ENT de la Organización Mundial de la Salud, un enfoque del marco de Flujos Múltiples e ideas de evaluación realistas.

Resultados. Los resultados positivos de las políticas más reportados incluyeron las actividades de promoción de la salud (por ej., los programas de comidas escolares) que consiguieron la colaboración multisectorial de diferentes instituciones gubernamentales tales como los ministerios de salud, educación y agricultura. Todavía existen grandes brechas políticas relacionadas con la creación de entornos legislativos, físicos y sociales que apoyen la alimentación saludable y la actividad física a nivel de la población. Las comisiones multisectoriales dedicadas a las ENT presentaron un alcance adecuado en todos los sectores, pero tuvieron una influencia limitada en el desarrollo de políticas. Se observaron diferentes niveles de políticas y las de nivel nacional fueron procesos prolongados; los programas "en el terreno" fueron más rápidos de implementar. Las barreras externas incluyeron la dependencia de las importaciones de alimentos permitidas por los acuerdos comerciales internacionales, que limitan la disponibilidad, la calidad y la asequibilidad de los alimentos saludables. La limitada legislación a nivel internacional para reducir las importaciones de alimentos y la ausencia de un marco internacional o regional, similar al Convenio Marco para el Control del Tabaco, dificulta aún más los esfuerzos.

Conclusiones. La colaboración regional y el apoyo político en todos los sectores son esenciales para acelerar el ritmo de acción en apoyo de una alimentación saludable y entornos que favorezcan una vida activa. Los "proyectos" de políticas podrían acelerar el proceso de desarrollo. Los "campeones regionales contra las ENT" podría liderar las estrategias y respuestas.

Palabras clave Enfermedades no transmisibles; formulación de políticas; política de salud; ejercicio; nutrición en salud pública; Región del Caribe. 
RESUMO Objetivo. Identificar, avaliar e comparar as políticas existentes sobre doenças não transmissíveis (DNT) no Caribe, as lacunas nas respostas e fatores que influenciam o desenvolvimento e implementação de políticas bem sucedidas depois da Declaração de Porto Espanha em 2007. Especificamente, examinar as políticas que apontam para

Avaliação de respostas políticas a doenças não transmissíveis em sete países do Caribe: desafios para abordar dietas não saudáveis e inatividade física dois fatores de risco de DNT: dietas não saudáveis e inatividade física.

Métodos. Um total de 76 entrevistas semi-estruturadas com 80 participantes diretos, pertencentes ao governo, ao setor privado e à sociedade civil, foram complementados com a análise de documentos sobre as políticas estabelecidas. As entrevistas foram analisadas pragmaticamente, enquadradas nos compromissos dos governos do CARICOM, no Plano de Ação das DNTs da Organização Mundial da Saúde, numa abordagem do quadro de fluxos múltiplos e em ideias de avaliação realistas.

Resultados. Os resultados positivos das políticas mais divulgados incluíram atividades de promoção da saúde (por exemplo, programas de alimentação escolar) que tiveram colaboração multissetorial de diferentes instituições governamentais, como os ministérios da saúde, educação e agricultura. Ainda existem grandes lacunas políticas em torno da criação de ambientes legislativos, físicos e sociais para apoiar a alimentação saudável e a atividade física no nível populacional. As comissões multissetoriais de ENT alcançaram com sucesso todos os setores, mas tiveram influência limitada no desenvolvimento de políticas. Diferentes níveis de políticas foram observados e aqueles em nível nacional foram processos prolongados; os programas "no terreno" foram mais rápidos para implementar. As barreiras externas incluíram a dependência de importações de alimentos permitidas por acordos comerciais internacionais que limitam a disponibilidade, qualidade e acessibilidade de alimentos saudáveis. A legislação internacionalmente limitada para reduzir as importações de alimentos e a ausência de um quadro internacional o regional, semelhante à Convenção-Quadro para o Controle do Tabaco, torna os esforços ainda mais difíceis.

Conclusões. A colaboração regional e o apoio político em todos os setores são essenciais para acelerar o ritmo de ação em apoio à alimentação saudável e a ambientes de vida ativa. Os "esquemas" de políticas podem acelerar o processo de desenvolvimento. Os "campeões regionais de ENT" poderiam liderar as estratégias e respostas.

Palavras-chave Doenças não transmissíveis; política de saúde; formulação de políticas; exercício; nutrição em Saúde Pública; Região do Caribe. 